\title{
PENGARUH UKURAN PERUSAHAAN, LEVERAGE DAN PROFITABILITAS TERHADAP PENERAPAN GOOD CORPORATE GOVERNANCE BISNIS SYARIAH BUS DI INDONESIA
}

\author{
Eliana $^{1)}$, Nurhayati ${ }^{2)}$, Ayumiati ${ }^{3)}$ \\ Sekolah Tinggi Ilmu Ekonomi Sabang (STIES) Banda Aceh ${ }^{1,2)}$, Fakultas Ekonomi \\ dan Bisnis Islam Universitas Islam Ar-Raniry ${ }^{3)}$ \\ Email:eliana@stiesabang.ac.id,nurhayati@stiesabang.ac.id,ayumiati@ar-
} raniry.ac.id

\begin{abstract}
The implementation of bad corporate governance does not only occur in the world's leading companies but in Indonesia also found several similar cases that befell several banks, namely Citibank and Bank Mega, both of these banks are known to violate the implementation of Good Corporate Governance which results in large losses and of course an impact on economic development. This study aims to determine the effect of company size, leverage, and profitability on the implementation of GCGBS in Islamic commercial banks in Indonesia. The sample used was 11 Islamic commercial banks. Regression test results explain that company size and leverage have no significant effect on the implementation of GCGBS in Islamic commercial banks, profitability has a positive and significant effect on the implementation of good corporate governance in Islamic business in Islamic commercial banks in Indonesia.
\end{abstract}

Keywords: Implementation GCGBS; Company Size; Leverage; Profitability

\begin{abstract}
Abstrak
Penerapan Corporate Governance yang buruk tidak saja terjadi pada perusahaan terkemuka dunia, tetapi di Indonesia ditemukan kasus serupa yang menimpa beberapa bank yaitu Citibank dan Bank Mega, kedua bank ini diketahui melanggar penerapan GCG yang mengakibatkan kerugian yang besar dan tentu saja berdampak pada perkembangan ekonomi. Adapun tujuan dari penelitian adalah seberapa besar pengaruh ukuran perusahaan, leverage dan profitabilitas terhadap penerapan GCGBS di Bank umum Syariah di Indonesia. Sampel yang digunakan 11 bank umum syariah. Hasil uji regresi menjelaskan bahwa ukuran perusahaan dan leverage tidak berpengaruh signifikan terhadap penerapan GCGBS di Bank Umum Syariah, profitabilitas berpengaruh positif dan signifikansi terhadap penerapan Good corporate governance Bisnis syariah di Bank Umum Syariah di Indonesia.
\end{abstract}

Kata kunci : Penerapan GCGBS; Ukuran Perusahan; Leverage; Profitabilitas 
Jurnal Akuntansi Berkelanjutan Indonesia - Vol. 3, No. 2, Mei 2020 - Eliana,

Nurhayati \& Ayumiyati

\section{PENDAhUluan}

Di Indonesia sekarang ini perkembangan perbankan sudah tidak lagi dipengaruhi oleh bank konvesional, yang memang lebih dulu memulai bisnis jasa bank, bank syariah pun sekarang sudah sangat populer di Indonesia, ini bisa dilihat dengan banyak bank konvesional membuka unit ke bank syariah di mana Indonesia masyarakatnya yang mayoritas berpenduduk islam. Maali et al (2006) menjelaskan bank syariah adalah bank yang transaksinya menggunakan standar islam. Dalam UU no 21 tahun 2008 bank syariah adalah bank yang menjalankan kegiatan usahanya dengan didasarkan prinsip islam dengan menjalankan tata kelola perbankan yang baik dan benar.

Tata kelola atau Corporate Governance menjadi wacana hangat untuk beberapa tahun terakhir. Hal ini dipicu oleh berita besar yang membuat dunia tersentak atas bangkrutnya perusahaan-perusahaan raksasa dunia pada tahun 1990an menjelang 2000-an. Pasalnya, terakhir diketahui bahwa penyebab beberapa perusahaan terkemuka dunia seperti WorldCom dan Enron Corporation adalah akibat belum adanya penerapan $G C G$ dengan baik. Penerapan Corporate Governance yang buruk tidak hanya terjadi pada perusahaan terkemuka dunia, namun di Indonesia juga ditemukan beberapa kasus serupa yang menimpa beberapa bank pada Mei 2011 Bank Indonesia mengeluarkan sanksi untuk dua bank sekaligus. BI kenakan sanksi untuk Citibank pada tanggal 6 Mei 2011 dan untuk Bank Mega pada tanggal 24 Mei 2011 (www.bi.go.id). Pasalnya, kedua bank ini diketahui melanggar penerapan Good Corporate Governance yang mengakibatkan kerugian besar dan tentu saja berdampak pada perkembangan ekonomi.

Banyak terjadi permasalahan di antaranya pemberian kredit yang melanggar batas maksimum, manajemen risiko yang praktiknya sangat rendah, informasi keuangan yang berikan kepada nasabah tidak transparan sama sekali, para pemenggang saham sangat mendominasi dalam pengaturan pengelolaan bank, sehingga industri perbankan di Indonesia rapuh. Oleh sebab itu banyak perusahaan terutama bank yang tidak mematuhi Good Corporate Govenance (Faozan, 2013).

Penerapan GCG juga berlaku untuk perbankan syariah, GGBS sendiri merupakan sebuah pedoman yang dibuat untuk menuntut tercapainya kelangsungan bisnis syariah dengan baik. Menurut KNKG (2011) dalam islam untuk menjalankan bisnis harus dijalan dengan tata kelola bagus yang diperlukan sabagai suatu upaya ibadah dan amal saleh yang berlandaskan ketaqwaan, sehingga diperlukan taat kepada asas spiritual dan operasional yang artinya untuk mendapatkan keberkahan, bermanfaat dan keberlangsungan dalam dunia dan akhirat yang akan dipertanggungjawabkan di hadapan Allah SWT.

Menurut data statistik Perbankan Syariah April 2019, Bank Umum Syariah yang terdaftar di OJK berjumlah 14 bank, jumlah kantor 4.187 kantor yang tersebar diseluruh Indonesia dan tercatat memiliki total aset sebesar Rp 314.602 Milyar. (Data Statistik Perbankan Syariah). Salah satu contoh yaitu Bank BNI Syariah merupakan BUS yang menerima penghargaan penerapan GCG 
Jurnal Akuntansi Berkelanjutan Indonesia - Vol. 3, No. 2, Mei 2020 - Eliana,

Nurhayati \& Ayumiyati

terbaik selama 3 kali berturut-turut, maka profitabilitas, leverage dan ukuran perusahaan patut diperhatikan

Ukuran perusahaan adalah faktor yang dapat diperhatikan dalam mengambil keputusan utang untuk dijalankan oleh perusahaan, ukuran perusahaan mencermikan besar dan kecil perusahaan, untuk melihat besar dan kecil perusahaan dapat ditentukan berdasarkan total penjualan, aset dan tingkat penjualan. Apabila jumlah aset yang dimiliki oleh perusahaan lebih besar, maka pendapatan yang didapat semakin meningkat velocity of money atau peredaran uang.

Perbankan Syariah perlu rasio keuangan yang mengukur jumlah utang di dalam perbankan syariah itu sendiri adalah leverage, karena sebuah perusahaan yang memiliki utang yang besar, dapat mengurangi dividen atau laba yang dibayarkan kepada pemilik, yang menyebabkan laba menurun sehingga perbankan tersebut akan ditinggalakan oleh investor. Menurut Astuti (2013) dalam dunia bisnis saat ini semua perusahaan tidak lagi dibiayai oleh modal dalam perusaah tetapi sudah didanai oleh modal utang dari pihak ketiga. Sehingga leverage menjelaskan seberapa banyak harta perbankan syariah bisa mendanai pembiayaan yang menghasilkan keuntungan untuk bank syariah.

Faktor lain yang berpotensi mempengaruhi GCG adalah Profitabilitas , menurut Ferdyant, et al (2014) profitabilitas merupakan rasio yang dijadikan tolak ukur kemampuan bank untuk memperoleh keuntungan dalam suatu jangka waktu tertentu dengan mengatur sumber daya yang dimiliki yaitu aset dan equity yang akan digunakan secara efiesien dan efektif. Dalam profitabilitas ada beberapa rasio yang digunakan yaitu rasio ROA, ROE, ROI dan EPS, tetapi dalam penelitian ini yang digunakan adalah rasio ROA, yakni rasio yang mengukur kesanggupan perusahaan mewujudkan keuntungan sebelumnya dan menghasilkan laba di masa yang akan datang.

\section{KERANGKA TEORITIS DAN PENGEMBANGAN HIPOTESIS}

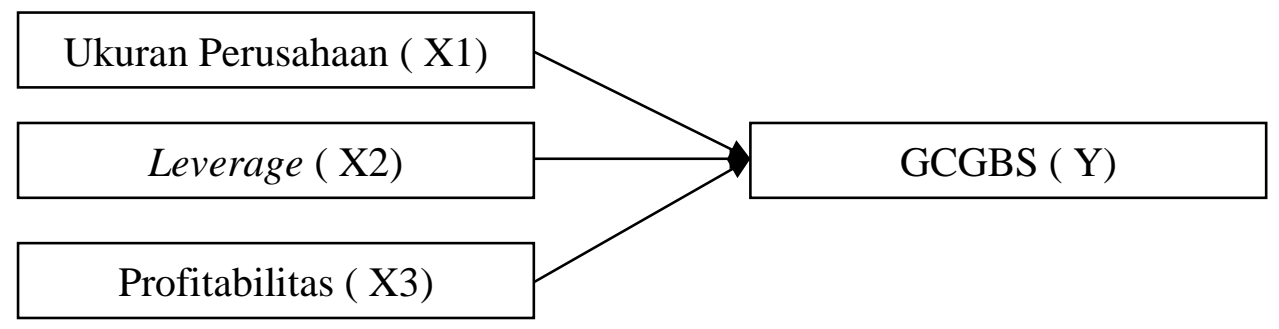

Hipotesis

Berdasarkan kerangka teori yang dipaparkan di atas, maka yang dijadikan hipotesis adalah sebagai berikut:

$\mathrm{H}_{1}$ : Ukuran Perusahaan, Leverage dan profitabilitas secara simultan berpengaruh positif terhadap Penerapan Good Corporate Governance Bisnis Syariah

$\mathrm{H}_{2}$ : Ukuran Perusahaan secara parsial berpengaruh positif terhadap Penerapan Good Corporate Governance Bisnis Syariah.

$\mathrm{H}_{3}$ : Leverage parsial berpengaruh positif terhadap Penerapan Good Corporate Governance Bisnis Syariah 
Jurnal Akuntansi Berkelanjutan Indonesia - Vol. 3, No. 2, Mei 2020 - Eliana, Nurhayati \& Ayumiyati

$\mathrm{H}_{4}$ : Profitabilitas parsial berpengaruh positif terhadap Penerapan Good Corporate Governance Bisnis Syariah

\section{METODE RISET}

Adapun Populasi yang dipergunakan didalam penelitian ini adalah seluruh BUS yang ada di Indonesia.

Tabel 1. Daftar Populasi Bank Umum Syariah di Indonesia

\begin{tabular}{|l|l|}
\hline No & \multicolumn{1}{|c|}{ NAMA BANK } \\
\hline 1 & PT. Bank Aceh Syariah \\
\hline 2 & PT. Bank Muamalat Indonesia \\
\hline 3 & PT. BRISyariah \\
\hline 4 & PT. BNI Syariah \\
\hline 5 & PT. BSM \\
\hline 6 & PT. BCA Syariah \\
\hline 7 & PT. Bank Tabungan Pensiunan Nasional Syariah \\
\hline 8 & PT. Bank Mega Syariah \\
\hline 9 & PT. Bank Syariah Bukopin \\
\hline 10 & PT. Maybank Syariah Indonesia \\
\hline 11 & PT. BPD Nusa Tenggara Barat Syariah \\
\hline 12 & PT. Bank Victoria Syariah \\
\hline 13 & PT. Bank Panin Dubai Syariah \\
\hline 14 & PT. Bank Jabar Banten Syariah \\
\hline
\end{tabular}

Sumber : Data Statistik Perbankan Syariah, 2019

\section{Sampel}

Sampel yang digunakan adalah laporan keuangan dan GCG yang dipublikasi oleh masing-masing Bank Umum Syariah di Indonesia. Dengan memakai data gabungan dari LK dan laporan GCG setiap bank selama 2016-2018 maka diperoleh jumlah data sebanyak 33 data pengamatan dari 3 periode.

Tabel 2. Karakteristik Pengambilan Sampel

\begin{tabular}{|l|l|c|c|}
\hline No & \multicolumn{1}{|c|}{ Kriteria Sampel } & $\begin{array}{c}\text { Tidak } \\
\text { Masuk } \\
\text { kriteria }\end{array}$ & Total \\
\hline 1 & $\begin{array}{l}\text { BUS terlist di Bank Indonesia dan } \\
\text { mempublikasikan laporan keuangan selama } \\
\text { periode pengamatan 2016 - 2018 }\end{array}$ & 14 \\
\hline 2 & $\begin{array}{l}\text { BUS yang mempublikasikan laporan GCG } \\
\text { tahun periode 2016 - 2018 }\end{array}$ & 3 & 11 \\
\hline 3 & Jangka waktu penelitian & & 3 \\
\hline
\end{tabular}

Sumber : Data sekunder, 2019 
Jurnal Akuntansi Berkelanjutan Indonesia - Vol. 3, No. 2, Mei 2020 - Eliana,

Nurhayati \& Ayumiyati

Sehingga dari semua populasi Bank Umum Syariah yang ada, hanya ada 11 Bank Umum Syariah yang dipergunakan sebagai kriteria yang telah ditetapkan. yaitu PT. BAS, PT. BRI Syariah, PT. BNIS, PT. MS, PT. BCAS, PT. BMS, PT. BBS , PT. Maybank, PT. Victoria Syariah, PT. Panin Dubai S, PT. Bank JBBS.

\section{Metode Analisis Data}

Metode analisa yang dilakukan dalam penelitian ini adalah uji kualitas data dan uji hipotesis, uji kualitas data digunakan metode regresi linier berganda menguji pengaruh variabel yang saling terikat satu sama lain. Kemudian perlu diketahui bukan variable $\mathrm{X}$ yang mempengaruhi variabel $\mathrm{Y}$ tetapi ada variabel lain yang bisa mempengaruhi dalam mengobservasi yaitu variabel error. Untuk menghasilkan nilai parametrik yang shahih maka perlu dilakukan uji asumsi klasik di antaranya uji normalitas, multikolinearitas, dan heteroskedastisitas. Dalam pengujian hipotesis dilakukan dengan metode regresi linear berganda, uji t, Uji F, dan koefisien determinasi.

\section{ANALISIS DATA DAN PEMBAHASAN}

\section{Dekriptif Data Penelitian}

\section{Statistik Deskriptif}

Statistics

\begin{tabular}{|c|c|c|c|c|c|}
\hline & & GCGBS & Ukuran & Leverage & Profitabilitas \\
\hline \multirow{2}{*}{$\mathrm{N}$} & Valid & 33 & 33 & 33 & 33 \\
\hline & Missing & 0 & 0 & 0 & 0 \\
\hline \multicolumn{2}{|c|}{ Mean } & 59.09 & 19.81 & 7.23 & 0.98 \\
\hline \multicolumn{2}{|c|}{ Median } & 58.33 & 7.44 & 6.91 & 0.59 \\
\hline \multicolumn{2}{|c|}{ Std. Deviation } & 9.977 & 25.078 & 3.783 & 1.127 \\
\hline \multicolumn{2}{|c|}{ Minimum } & 39 & 6 & 31 & 0 \\
\hline \multicolumn{2}{|c|}{ Maximum } & 81 & 99 & 20.45 & 6 \\
\hline
\end{tabular}

Berdasarkan hasil yang diperoleh bahwa nilai terendah, tertinggi, rata-rata dan standar deviasi dari variabel yang diteliti pada bank umum syariah tahun 2016-2018. Sampel sasaran adalah 11 BUS untuk 3 tahun pengamatan (33 data sampel). Nilai minimum good governace bisnis syariah yang merupakan variabel dependen sebesar 39 dapat diartikan jumlah penerapan yang dihasilkan oleh bank umum syariah adalah sebesar $39 \%$ dari total yang diharapkan dan nilai paling tinggi berjumlah 81 yang berarti bahwa bank umum syariah telah melakukan penerapan GGBS secara sempurna sesuai dengan daftar item GGBS yang diharapkan. Tingkat standar deviasi adalah sebesar 9.977.

Variabel ukuran perusahaan diperoleh dari log total aktiva perusahaan. Nilai maksimum ukuran perusahaan sebesar 99 dimiliki oleh PT BSM yang berarti selama periode pengamatan BUS pernah memiliki total aktiva paling besar yaitu 99\%. Nilai minimum sebesar 6 dimiliki oleh PT. May Bank yang berarti 
Jurnal Akuntansi Berkelanjutan Indonesia - Vol. 3, No. 2, Mei 2020 - Eliana,

Nurhayati \& Ayumiyati

bahwa selama periode pengamatan perusahaan pernah memiliki total aktiva paling sedikit yaitu sebesar 6\%. Nilai rata-rata diperoleh sebesar 19.81 yang berarti selama periode pengamatan total aktiva dimiliki bank umum syariah sebesar $19.81 \%$ dari total aktiva. Tingkat standar deviasi adalah sebesar 25.078.

Variabel leverage dinilai dengan DER yaitu dari perbandingan total hutang dengan ekuitas pemegang saham. Nilai maksimum dimiliki oleh PT BSM dengan perolehan sebesar 20.45 yang berarti bahwa selama periode pengamataan perusahaan pernah memiliki hutang sebesar $20 \%$ dari total modal. Nilai terendah 0,31 dimiliki oleh PT. May Bank yang berarti selama periode pengamatan bank umum syariah pernah memiliki hutang paling rendah sebesar $31,0 \%$. Nilai ratarata sebesar 7.23 yang dapat diartikan bahwa hutang yang dimiliki Bank Umum Syariah selama periode pengamatan sebesar $7.23 \%$ dari total modal. Tingkat standar deviasi adalah sebesar 3.783.

Variabel independen profitabilitas diukur dengan ROA dapat dijelaskan bahwa perbandingan antara total asset dengan laba bersih setelah pajak. Nilai maksimum profitabilitas diperoleh sebesar 6,0 dan dimiliki oleh PT. Bank BRISyariah yang berarti bahwa selama periode pengamatan bank umum syariah pernah memiliki laba paling tinggi sebesar 6,0\% dari total aset. Nilai minimum sebesar 0,001 dimiliki oleh PT. May Bank dan PT. Bank Jabar Banten Syariah yang berarti bahwa selama periode pengamatan perusahaan tersebut pernah memiliki laba paling rendah sebesar $0,1 \%$ dari total aset. Nilai rata-rata profitabilitas diperoleh sebesar 0,98 , artinya selama periode pengamatan bank umumsyariah memiliki rata-rata laba sebesar $98,0 \%$ dari total aset. Tingkat standar deviasi adalah sebesar 1.127.

\section{Uji Normalitas}

\section{Gambar 1. Hasil Uji Normalitas}

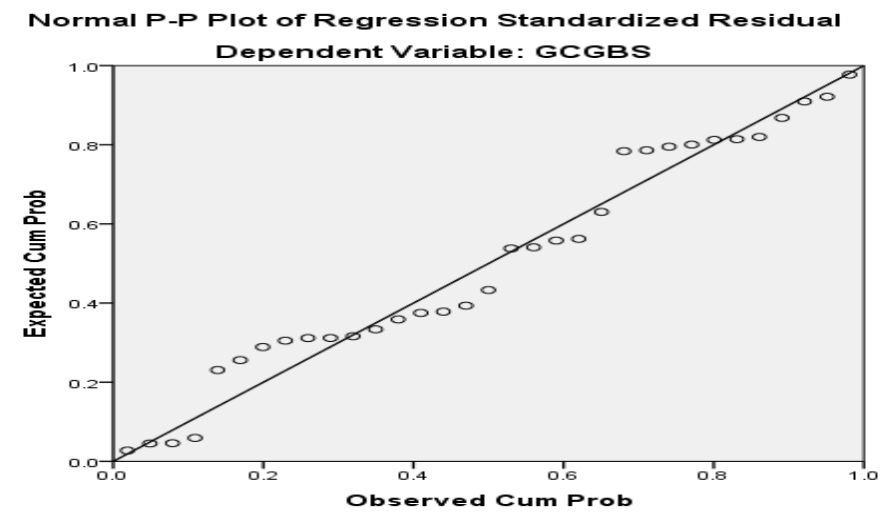

Gambar 2. Histogram dan Normal Probability Plot 
Jurnal Akuntansi Berkelanjutan Indonesia - Vol. 3, No. 2, Mei 2020 - Eliana, Nurhayati \& Ayumiyati

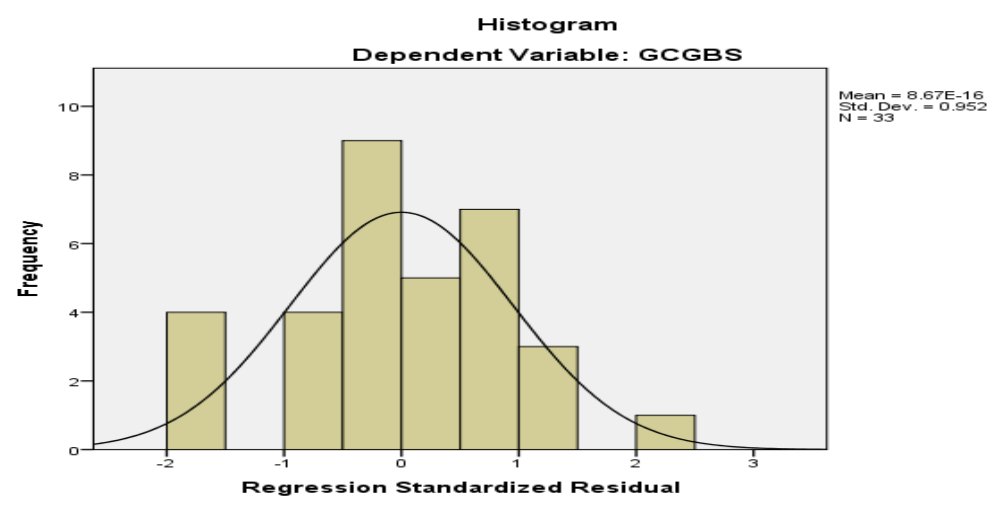

Hasil di atas dapat disimpulkan bahwa titik menjangkau di antara garis diagonal dan mengikuti arah garis tersebut. Maka disimpulkan bahwa penyebaran dat terdistribusi normal. Begitu juga tampilan grafik histogram mendukung hasil dari grafik 1.

\section{Uji Multikolinearitas}

Tabel 3. Hasil uji Multikolinearitas

\begin{tabular}{|l|c|c|}
\hline \multicolumn{1}{|c|}{ Variabel } & Tolerance & VIF \\
\hline Ukuran Perusahaan & 0.869 & 1.151 \\
\hline Leverage & 0.867 & 1.151 \\
\hline Profitabilitas & 0.998 & 1.002 \\
\hline
\end{tabular}

Berdasarkan tabel 3 dijelaskan di atas bahwa nilai VIF dari masing-masing variabel independen berada di angka 1, ini berasumsi bahwa tidak terjadi multikolinearitas dalam model regresi.

\section{Uji Heteroskedastisitas}

\section{Gambar 3. Diagram Scatterplot}

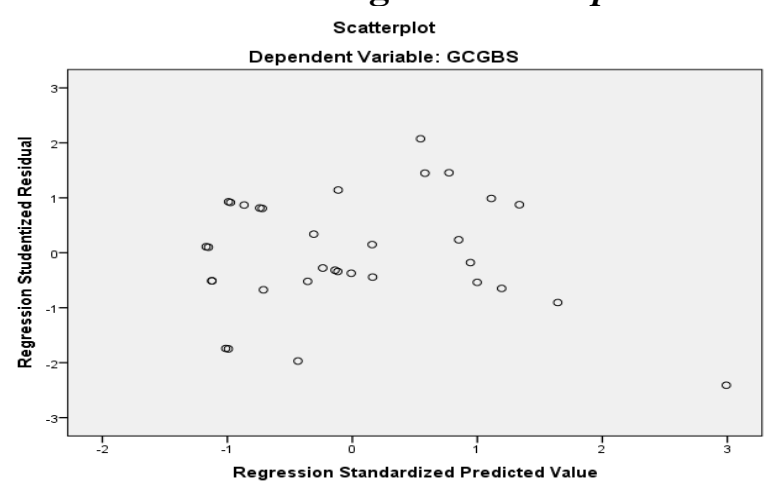

Dengan melihat gambar 3 bahwa titik menyebar dari atas kebawah 0 pada sumbu Y, maka dapat dikatakan tidak terjadi heteroskedastisitas. 
Jurnal Akuntansi Berkelanjutan Indonesia - Vol. 3, No. 2, Mei 2020 - Eliana,

Nurhayati \& Ayumiyati

Hasil Uji Regresi Linear Berganda

Tabel 4 Pengaruh variabel independen terhadap variabel dependen

Coefficients $^{\mathrm{a}}$

\begin{tabular}{|c|c|c|c|c|c|}
\hline \multirow[t]{2}{*}{ Model } & \multicolumn{2}{|c|}{$\begin{array}{l}\text { Unstandardized } \\
\text { Coefficients }\end{array}$} & $\begin{array}{c}\text { Standardized } \\
\text { Coefficients }\end{array}$ & $\mathrm{t}$ & Sig. \\
\hline & B & Std. Error & Beta & & \\
\hline (Constant) & 52.134 & 3.879 & & 13.439 & 0.000 \\
\hline Ukuran_Perusahaan & 0.052 & 0.077 & 0.210 & 0.669 & 0.509 \\
\hline Leverage & 0.435 & 0.513 & 0.165 & 0.849 & 0.403 \\
\hline Profitabilitas & 2.849 & 1.499 & 0.322 & 1.900 & 0.004 \\
\hline
\end{tabular}

a. Dependent Variable: GCGBS

Berdasarkan Tabel 4 persamaan regresi dapat diketahui:

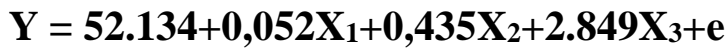

Persamaan di atas dapat katakan sebagai berikut:

- Kostanta $(\alpha)$ 52.134. Artinya jika ukuran perusahaan $\left(\mathrm{X}_{1}\right)$, leverage $\left(\mathrm{X}_{2}\right)$, dan profitabilitas $\left(\mathrm{X}_{3}\right)$ dianggap konstan, maka besarnya indeks penerapan GGBS adalah 52.134. Angka ini menunjukkan bahwa BUS yang diteliti ini telah memiliki kesediaan untuk menerapkan tata kelola yang baik.

- Koefisien regresi untuk ukuran perusahaan $\left(X_{1}\right)$ sebesar 0,052 membuktikan bahwa setiap penambahan satu satuan total aktiva akan meningkatkan indeks GGBS sebesar 0,052. Dengan faktor yang lain yang dipengaruh dianggap konstan.

- Koefisien regresi untuk leverage $\left(\mathrm{X}_{2}\right)$ sebesar 0,435 menerangkan bahwa setiap menaikan 1,00 x pada DER akan menambah indeks penerapan GGBS sebesar 0,435 . Dalam hal ini faktor lain yang mempengaruhi dianggap konstan.

- Koefisien regresi untuk profitabilitas $\left(\mathrm{X}_{3}\right)$ sebesar 2.845 mengungkapkan bahwa setiap penambahan 1,00 x pada ROA akan menambah penerapan GGBS sebesar 2.849 yang lain konstan.

\section{Uji F}

Hasil SPSS menunjukkan tabel ANOVA dimana nilai signifikansi F-nya sebesar 0,000 lebih sedikit dari 0,05. Dapat diterangkan secara simultan berpengaruh antara ukuran perusahaan, leverage, dan profitabilitas terhadap penerapan GCGBS ada Bank Umum Syariah di Indonesia dapat diterima sesuai dengan hipotesi pertama

\section{Uji T}

a. Variabel ukuran perusahaan (X1) mempunyai t-hitung sebesar 0,669 dengan signifikansi 0,509 (50,9\%) yang berada di atas taraf signifikansi 0,05 (5\%). Ini mendeskripsikan bahwa ukuran perusahaan tidak berpengaruh signifikan 
Jurnal Akuntansi Berkelanjutan Indonesia - Vol. 3, No. 2, Mei 2020 - Eliana,

Nurhayati \& Ayumiyati

terhadap penerapan good corporate governance bisnis syariah pada bank umum syariah.

b. Variabel leverage (X2) memiliki t-hitung sebesar 0,849. Dengan signifikansi $0,403(40,3 \%)$ yang berarti berada di atas taraf signifikansi 0,05 (5\%). Hal ini menunjukkan bahwa tidak terdapat pengaruh signifikan dari leverage terhadap penerapan good corporate governance bisnis syariah pada bank umum syariah.

c. Variabel profitabilitas (X3) memiliki t-hitung sebesar 1,900. Bahwa dapat diterangkan t-hitung $>\mathrm{t}$-tabel, dari hasil SPSS, nilai t-hitung sebesar 1,900 berada dalam taraf signifikansi $0,004(0,4 \%)$ yang berarti berada di bawah taraf signifikansi $0,05(5 \%)$. Hal ini ditunjukkan bahwa profitabilitas berpengaruh positif dan signifikan terhadap penerapan good corporate governance bisnis syariah pada bank umum syariah

\section{Koefisien Determinan}

Tabel 5 Nilai Koefisien Determinasi Model Summaryb

\begin{tabular}{|l|r|r|r|r|}
\hline Model & R & R Square & $\begin{array}{c}\text { Adjusted R } \\
\text { Square }\end{array}$ & $\begin{array}{c}\text { Std. Error of the } \\
\text { Estimate }\end{array}$ \\
\hline 1 & $0.413^{\mathrm{a}}$ & 0.171 & 0.085 & 9.544 \\
\hline
\end{tabular}

a. Predictors: (Constant), Profitabilitas,

Ukuran_Perusahaan, Leverage

b. Dependent Variable: GCGBS

Tabel 5 memperlihatkan nilai $R$ Square sebesar 0,171. Artinya 17,1 persen GCCBS dapat dijelaskan oleh ketiga variabel bebas, sisanya 82,9 persen lagi dipengaruhi oleh varibel lain.

\section{Pembahasan}

\section{Pengaruh Ukuran Perusahaan terhadap Penerapan GCGBS}

Tabel 4 menunjukkan Variabel ukuran perusahaan (X1) mempunyai t-hitung sebesar 0,669 dengan signifikansi 0,509 (50,9\%) yang berada di atas taraf signifikansi $0,05(5 \%)$. Yang artinya ukuran perusahaan tidak berpengaruh signifikan terhadap GCBBS di BUS.bahwa ukuran perusahaan tidak hanya melihat perusahaan dengan dana besar tetapi bisa juga dilihat dari rasio-rasio lain seperti rasio likuiditas, solvabilitas dan bisa dari laba yang didapat oleh perusahaan

\section{Pengaruh Leverage terhadap Penerapan GCGBS}

Tabel 4 menunjukkan t-hitung sebesar 0,849 dengan signifikansi 0,403 (40,3 $\%$ ) yang berarti berada di atas taraf signifikansi 0,05 (5\%). Hal ini menunjukkan bahwa tidak berpengaruh signifikan dari leverage terhadap Penerapan GCGBS pada Bank Umum Syariah di Indonesia. jika entitas yang memakai utang berkelanjutan, maka kewajiban yang di bayar akan semakin tinggi. Oleh karena itu entitas lebih mengutamakan bayar utang dari pada kegiatan operasional 
Jurnal Akuntansi Berkelanjutan Indonesia - Vol. 3, No. 2, Mei 2020 - Eliana,

Nurhayati \& Ayumiyati

lainnya. Ini sesuai penelitian Bajuri (2011), Wijaya (2012) yang menemukan tidak adanya pengaruh leverage terhadap Penerapan GCG Bisnis Syariah.

\section{Pengaruh Profitabilitas terhadap Penerapan GCGBS}

Tabel 4 menunjukkan memiliki t-hitung sebesar 1,900 dan berada dalam taraf signifikansi 0,004 (0,4 \%). yakni berada di bawah taraf signifikansi 0,05 (5 $\%$ ). Dapat dijelaskan bahwa profitabilitas berpengaruh positif dan signifikan terhadap penerapan good corporate governance bisnis syariah di Bank Umum Syariah. GCGBS sendiri merupakan pedoman yang dibuat untuk menjembatani kepentingan sebuah perusahaan guna memperoleh keuntungan, sehingga sistem pengelolaan yang bagus harus di tingkatkan. Hasil penelitian ini sejalan dengan hipotesis bahwa kemampuan sebuah perusahaan memperoleh laba sangat diharapkan bagaimana sebuah perusahaan menerapkan Good Corporate Governance. Penelitian yang dilakukan oleh Hapsari (2018), menyatakan hasil berpengaruh positif dan signifikan antara GCG dan ROE. Begitu pula penelitian Himawan (2016) yang menyatakan bahwa GCG berpengaruh signifikan terhadap ROA.

\section{KESIMPULAN DAN SARAN}

Simpulan yang dapat ditarik bahwa Ukuran Perusahaan, leverage, dan profitabilitas secara simultan berpengaruh terhadap penerapan Good corporate governance Bisnis syariah di Bank Umum Syariah di Indonesia. Ukuran Perusahaan secara parsial tidak berpengaruh signifikansi terhadap penerapan Good corporate governance Bisnis syariah di Bank Umum Syariah di Indonesia. Leverage secara parsial tidak berpengaruh signifikansi terhadap penerapan Good corporate governance Bisnis syariah di Bank Umum Syariah di Indonesia. Sedangkan Profitabilitas secara parsial berpengaruh positif dan signifikansi terhadap penerapan Good corporate governance Bisnis syariah di Bank Umum Syariah di Indonesia.

Saran Bagi pihak manajemen hendaknya memotivasi untuk menjalankan GCG secara eksis agar bisa meningkatkan ukuran perusahaan, leverage dan profitabilitas dan diharapkan penerapan GGBS harus dievaluasi terus menerus agar menjadi lebih baik dengan demikian dapat mengelola perusahaan menjadi lebih akuntabiltas dan transparan.

\section{DAFTAR PUSTAKA}

Astuti, Tri Puji. (2014). Faktor-Faktor yang mempengaruhi Pengungkapan Islamic Social Reporting (ISR) pada Bank Syariah Indonesia. Naskah Publikasi. Fakultas Ekonomi dan Bisnis Universitas Muhammadiyah Surakarta.

Badjuri, Achmad. (2011). Faktor-faktor fundamental, mekanisme coorporate governance, pengungkapan coorporate social responsibility pada 
Jurnal Akuntansi Berkelanjutan Indonesia - Vol. 3, No. 2, Mei 2020 - Eliana,

Nurhayati \& Ayumiyati

perusahaan manufaktur dan sumber daya alam di Indonesia. Jurnal Dinamika Keuangan dan Perbankan, Mei. Vol. 3, No. 1 : 38-54.

Faozan, Ahmad. (2013). Implementasi good Corporate Governance dan peran dewan pengawas Syariah di bank syariah. Jurnal Ekonomi Islam 7. (1): 114.

Ferdyant, Erly. Ratna Anggraini ZR, Erika Takidah. (2014). Pengaruh Kualitas Penerapan Good Corporate Governance dan Risiko Pembiayaan terhadap Profitabilitas Perbankan Syariah

Farook, S. Z., \& Lanis, R. (2003). Banking on Islam? Determinants of CSR isclosure. International Conference on Islamic Economics and Finance

Hapsari, Karina. (2018). Pengaruh Good Corporate Governance Terhadap Kinerja Keuangan Di Bank Umum Syariah Pada Tahun 2013-2015

Komite Nasional Kebijakan Governance (KNKG). (2011). Pedoman umum good corporate governance di Indonesia. Jakarta.

Maali, B., Casson, P., Napier, C. (2006). Social Reporting by Islamic Banks. ABACUS, 42 (2), pp 266-289

Sulastini, Sri. (2007). Pengaruh Karakteristik Perusahaan Terhadap Social Disclusure Perusahaan Manufaktur yang telah Go Public. Skripsi. Semarang: Universitas Negeri Semarang.

Utari, Lisna. (2010). Effect On Company Characteristics Corporate Social Responsibility Disclosures In Corporate Annual Report Of Consumptions Listed In Indonesia Stock Exchang. E-Jurnal Universitas Gunadarma. No.2 : 17-29.

Wijaya, M. (2012). Faktor-faktor yang mempengaruhi pengungkapan tanggung jawab sosial pada perusahaan manufaktur yang terdaftar di Bursa Efek Indonesia. Jurnal Ilmiah Mahasiswa Akuntansi. Vo. 1, No. 1 : 26-30. 